\title{
Effect of composition and depth of filter-bed on the efficiency of Sand-intermittent-filter treating the Industrial wastewater at Haridwar, India
}

\author{
Rakesh Bhutiani \\ Limnology and ecological modelling laboratory, Department of Zoology \& Environmental \\ Sciences, Gurukula Kangri Vishwavidyalaya, Haridwar-249404 (UK), India \\ Faheem Ahamad* \\ Department of Environmental Sciences, Keral Verma Subharti College of Sciences, \\ (KVSCOS), Swami Vivekanand Subharti University Meerut-250005 (UP), India \\ Mukesh Ruhela \\ Department of Environmental Engineering, SITE, Swami Vivekanand Subharti University \\ Meerut-250005 (UP), India \\ ${ }^{*}$ Corresponding author. Email: faheem.ahamad170390@gmail.com
}

\section{Article Info}

https://doi.org/10.31018/

jans.v13i1.2421

Received: November 6, 2020

Revised: February 1, 2021

Accepted: February 8, 2021

\section{How to Cite}

Bhutiani, R. et al. (2021). Effect of composition and depth of filter-bed on the efficiency of Sand-intermittent-filter treating the Industrial wastewater at Haridwar, India. Journal of Applied and Natural Science, 13(1): 88 - 94. https://doi.org/10.31018/ jans.v13i1.2421

\begin{abstract}
Sand Intermittent Filtration (SIF) is an established technology of wastewater treatment and in recent years it gains renewed interest due to its simplicity and less energy requirement. The aim of the present study was to evaluate the modified filter-bed Reactor using Sand-intermittent-filtration (SIF) for the removal of physicochemical parameters viz dissolved oxygen (DO), biochemical oxygen demand (BOD), chemical oxygen demand (COD), total hardness (TH), calcium hardness (CaH), chloride (Cl), turbidity, total solids (TS), total dissolved solids (TDS), and total suspended solids (TSS) of the Industrial wastewater of State Industrial Development Corporation of Uttarakhand Limited (SIDCUL) at Haridwar. The experiments were performed with the composition of the filter-bed having sand and gravel in the ratio of 1:1 (Reactor I); 1:2 (Reactor II) and 2:1 (Reactor III) at the room temperature $30^{\circ} \mathrm{C}$. Each Reactor was categorized into $A, B$ and $C$ type based on depth of filter-bed $(A=10 \mathrm{~cm}, B=15 \mathrm{~cm}$, $\mathrm{C}=30 \mathrm{~cm})$. The maximum removal of TS $(52.21 \%)$, TDS $(50.66 \%)$, TSS $(57.20 \%)$, turbidity $(67.36 \%)$, chloride $(28.81 \%)$, BOD (39.18\%), COD (38.66\%), TH (53.40\%), and CaH (62.57\%) was observed in Reactor II C (soil and gravel- 2:1 and $30 \mathrm{~cm}$ depth of bed) using $0.49 \mathrm{~mm}$ effective size and 0.49 uniformity coefficient (UC) of the sand. A mixture of sand and gravel in the Reactor II with a ratio of 2:1 yielded better efficiency in comparison to the Reactor I and Reactor III. Thus, SIF technology could be environment-friendly and economically cost-effective for removing various physicochemical parameters from Industrial wastewater.
\end{abstract}

Keywords: Biolayer, Reactor, Sand, wastewater, Sand intermittent filtration, SIDCUL

\section{INTRODUCTION}

Water is important as well as a poorly managed resource in the world. International Water Management Institute (IWMI) predicts that per capita domestic water demand in India is likely to increase from the estimated $31 \mathrm{M}^{3} /$ person/year in 2000 to about 46 and 62 $\mathrm{M}^{3} /$ person/year by 2025 and 2050 respectively and per capita annual water availability has declined form 5,177 cubic metres in 1951 to 1,545 cubic metres in
2011 (IWMI, 2007; Ibrahim et al., 2020). The IWMI also predicts that by 2025 one person in three will live in an absolute water scarcity condition (IWMI, 2007; Sahu et al., 2019). Although our needs for water are growing continuously, the quantity of water is still the same for consumption and after every two or three years, we observe a tremendous increase in the use of the quantity of water. We all know that we should do. We can do what we can for the conservation and protection of this precious resource. We also must 
purify and reuse the water we presently waste (Aghalari et al., 2020).

The wastewater treatment is the removal of pollutants present in wastewater such as organic matter, suspended and dissolved inorganic solids, nutrients, pathogens, refractory organics, microplastics, pharmaceutical residues, organic dyes, and heavy metals (Cheremisinoff, 2019 and Ruhela et al., 2019) to make it suitable for reuse in agriculture, car washing, floor washing, and gardening.

The performance of biological sand filtration (BSF) is controlled by an ecosystem of living organisms (biolayer or schmutzdecke) whose activities are affected by the raw water quality, and in particular, by the temperature (Campos et al., 2002; Prasad et al., 2006) and by chlorine concentration (Chuang et al., 2011). Among various wastewater treatment methods, sand filtration is an eco-friendly approach with low construction and maintenance cost and considerable wastewater treatment (D'Alessio et al., 2015; Ochoa et al, 2018; Ibrahim et al., 2020). The quality of the treated water and the system's maintenance requirements depend on selected variables like sand size, flow rate, and sand bed depth. In the present study, an attempt has been made to assess the impact of two different variables such as composition and depth of filter bed of the Reactors on their treatment efficiency of the Industrial wastewater of SIDCUL Industrial Area, Haridwar.

\section{MATERIALS AND METHODS}

\section{Study area}

The State Industrial Development Corporation of Uttarakhand (SIDCUL) Haridwar was established in 2000 with an area 1215 acres having about 585 different type of industries (textiles, pharmaceutical, plastics and allied, paper and packaging, electrical and electronics, food and agro, metal and fabrication, chemicals and general manufacturing industries etc.) with a Common Effluent Treatment Plant (CETP).

\section{Methodology}

The wastewater (WW) generated from the SIDCUL Industrial area, Haridwar was collected from the drain behind CETP, brought to the laboratory immediately, and used for the Sand-intermittent filtration. Three Reactors- Reactor I, Reactor II and Reactor III were prepared as shown in Fig. 1. The Reactor had a capacity 20 liters having diameter $(25 \mathrm{~cm})$ and height $(40 \mathrm{~cm})$. The height of each Reactor was $80 \mathrm{~cm}$. Each Reactor was divided into $A, B$, and $C$ types based on filter bed depth of $15 \mathrm{~cm}, 20 \mathrm{~cm}$ and $30 \mathrm{~cm}$ respectively. The sand and gravel used for these three Reactors were in the ratio of $1: 1,2: 1$ and $1: 2$, respectively. After preparation, the Reactors were provided moisture for several days (4 to 6 days) for the development of biological film (schmutzdecke) on the sand particles. After 6 days, the purifying bacteria were developed in the form of biological film. The previous study has reported that the development of biological film on sand particles is the important part of the treatment process (Bhutiani et al., 2017; Ranjan and Prem, 2018; Matuzahroh et al., 2020).

The wastewater before and after treatment with each type of the Reactor was analyzed for different physicochemical parameters viz. $\mathrm{pH}$, total dissolved solids (TDS), total suspended solids (TSS), total solids (TS), dissolved oxygen (DO), biochemical oxygen demand (BOD), chemical oxygen demand (COD), Chloride, total hardness $(\mathrm{TH})$, and calcium hardness $(\mathrm{CaH})$ following the Standard methods (APHA, 2012) and Khanna and Bhutiani, 2008).

As the system's efficiency and maintenance depended on the sand size, flow rates, and sand bed depth, the effective size (ES) and uniformity coefficient (UC) were the characteristics for the selection of sand. d10 was the sieve size which retained $10 \%$ of the total material sieved and d60 was the sieve size which retained $60 \%$ of the total material sieved. For the calculation of $\mathrm{d} 10$, d60, ES, and UC, 5000gm of sand was mechanically sieved and the fractions obtained at each sieve were weighed. The effective size and uniformity coefficient of sand were used $0.49 \mathrm{~mm}$ and 2.19 , respectively. The filtration rate was controlled at 0.5 Litre per hour with the help of a control valve.

The dimensions of the Reactors and variables of filtermedia (sand and gravel) used in the experiments are given in Table 1. The filter media (sand and gravel) were washed thoroughly before and after the sieving process and oven-dried $105^{\circ} \mathrm{C}$ for 12 to 24 hours. Before starting the experiment, the filter media was made moist with the mixture of sample and tap water and kept moist for 4 to 6 days for the formation of a microbial layer on the surface of soil and gravel.

The efficiency of Reactor was calculated using the following equation-

$$
\text { Efficiency of the reactor }=\left(\frac{\mathrm{C}_{\mathrm{i}}-\mathrm{C}_{\mathrm{f}}}{\mathrm{C}_{\mathrm{i}}}\right) \times 100 \quad \ldots \ldots . \text { Eq. } 1
$$

Where,

$\mathrm{C}_{\mathrm{i}}=$ Initial concentration of parameter (before treatment) $\mathrm{C}_{\mathrm{f}}=$ Final concentration of parameter (after treatment)

\section{RESULTS AND DISCUSSION}

The results of physicochemical parameters $(\mathrm{pH}, \mathrm{TDS}$, TSS, TS, DO, BOD, COD, Chloride, TH, and $\mathrm{CaH}$ ) of inlet (before treatment), outlet (after treatment) and percentage removal by all the Reactors (Reactor I-A to C, Reactor II-A to C; and Reactor III A to C) are given in Table 2.

In the present study, the $\mathrm{pH}$ of the treated water varied 


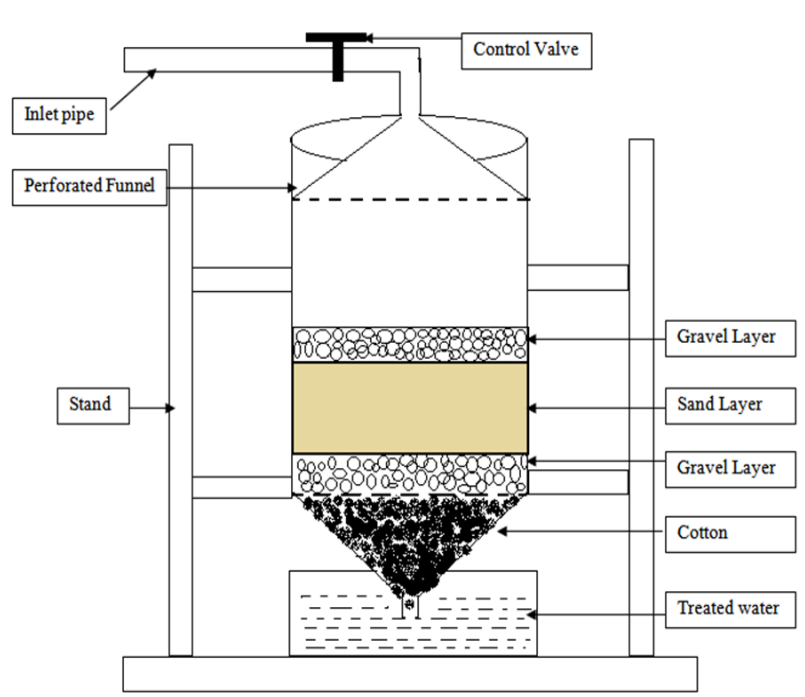

Fig. 1. Showing the sketch of the prepared Reactor system based on the principle sand intermittent filtration.

from 7.63 to 8.03 , which was in the range of MOEF standards (2000) for discharge in inland surface water. The reduction of $\mathrm{pH}$ ranged from $1.23 \%$ to $6.15 \%$ using all the reactors. Among the Reactors, Reactor II C showed maximum reduction $(6.15 \%)$ with a $30 \mathrm{~cm}$ depth of filter bed. Bhausaheb et al. (2010) obtained $8 \%$ reduction of $\mathrm{pH}$ due to filtration media and depth of filtration bed using fine sand, coarse size bricks, charcoal, and wooden sawdust, and coconut shell covers which were also below the standards. Zheng et al. (2009) used the sand bed of $70 \mathrm{~cm}$ depth and observed less than $1 \%$ reduction in $\mathrm{pH}$, but in our study we observed $1.23 \%$ to $6.15 \%$ reduction in $\mathrm{pH}$.

The removal of the TS was found in the range of $34.45 \%$ to $52.21 \%$. The maximum removal of TS was $52.21 \%$ (from $1296.67 \mathrm{mg} / \mathrm{l}$ to $619.67 \mathrm{mg} / \mathrm{l}$ ) with the Reactor II C using $30 \mathrm{~cm}$ depth of filter bed. The removal of the TDS was found in the range of $34.01 \%$ to
$50.66 \%$. The maximum removal was $50.66 \%$ (from $989.00 \mathrm{mg} / \mathrm{l}$ to $488.00 \mathrm{mg} / \mathrm{l}$ ) with the Reactor II C using $30 \mathrm{~cm}$ depth of filter bed. TDS in the wastewater indicates the presence of various ions of the elements.

The efficiency of the reactor for TSS removal was observed in the range of $35.86 \%$ to $57.20 \%$. Its maximum reduction was $57.20 \%$ (from $307.67 \mathrm{mg} / \mathrm{l}$ to $131.67 \mathrm{mg} / \mathrm{l}$ ) with the Reactor II C using $30 \mathrm{~cm}$ depth of filter bed which was found above the standard limit (MOEF, 2000) of discharge in inland surface water. Prasad et al. (2007) observed the TSS reduction of $35.85 \%$ to $94.16 \%$ using $1,1.5$ and 2 feet depth of the sand bed. However, Al-Enazi et al. (2013) observed the $97.2 \%$ reduction in TSS using $80 \mathrm{~cm}$ depth of the sand bed. Ibrahim et al. (2020) observed the $46 \%$ to $97 \%$ reduction of TSS using the only sand bed of depth of $60 \mathrm{~cm}$ to $120 \mathrm{~cm}$. The present study revealed that the slight variation in results from the other researchers might be due to variation of sand and gravel size as well as the depth of the bed in the Reactors. It was interesting to note that the mixture of soil and sand worked as a sieve for the removal of solids which increased the retention time of wastewater into sand bed of the Reactors. Aslam et al. (2007) have also indicated that the removal may be due to the retention of the solid particles in the filtration bed, which can cause significant depletion of these parameters. Al-Enazi et al. (2013) studied the Olive mill wastewater treatment with sand filter and stated that the low effective size was much better than high effective size for the removal of solids but in case of filter, it reduced the filter life.

Turbidity is considered as the criteria pollutant for the determination of the efficiency of sand filters. The removal of turbidity was found in the range of $42.73 \%$ to $67.36 \%$. The maximum reduction in turbidity was observed $67.36 \%$ (from 112.33 NTU to 36.67 NTU) with

Table 1. Showing the dimensions of the Reactors and filter-media used (sand and gravel).

\begin{tabular}{|c|c|c|c|c|}
\hline SN & Variables & Reactor I & Reactor II & Reactor III \\
\hline 1 & No. of layers & 2 & 3 & 3 \\
\hline 2 & Ratio & $\begin{array}{l}\text { Sand and Gravel (Ratio- } \\
1: 1)\end{array}$ & $\begin{array}{l}\text { Sand and Gravel (Ratio- } \\
2: 1 \text { ) }\end{array}$ & Sand and Gravel (Ratio-1:2) \\
\hline 3 & Depth of layers & $\begin{array}{l}\text { Reactor I } A=15 \mathrm{~cm} \\
\text { Reactor I } B=20 \mathrm{~cm} \\
\text { Reactor I } C=30 \mathrm{~cm}\end{array}$ & $\begin{array}{l}\text { Reactor II } A=15 \mathrm{~cm} \\
\text { Reactor II } B=20 \mathrm{~cm} \\
\text { Reactor II } C=30 \mathrm{~cm}\end{array}$ & $\begin{array}{l}\text { Reactor III } A=15 \mathrm{~cm} \\
\text { Reactor III } B=20 \mathrm{~cm} \\
\text { Reactor III } C=30 \mathrm{~cm}\end{array}$ \\
\hline 4 & d10 for sand & 0.49 & 0.49 & 0.49 \\
\hline 5 & d60 for sand & 1.07 & 1.07 & 1.07 \\
\hline 6 & $\begin{array}{l}\text { Uniformity Coefficient } \\
\text { (UC) for sand }\end{array}$ & 2.19 & 2.19 & 2.19 \\
\hline 7 & Effective size & 0.49 & 0.49 & 0.49 \\
\hline 8 & Flow rate & 0.5L/Hour & $0.5 \mathrm{~L} /$ Hour & $0.5 \mathrm{~L} / \mathrm{Hour}$ \\
\hline 9 & Size of gravel used & 3 to $4 \mathrm{~mm}$ & 3 to $4 \mathrm{~mm}$ & 3 to $4 \mathrm{~mm}$ \\
\hline
\end{tabular}




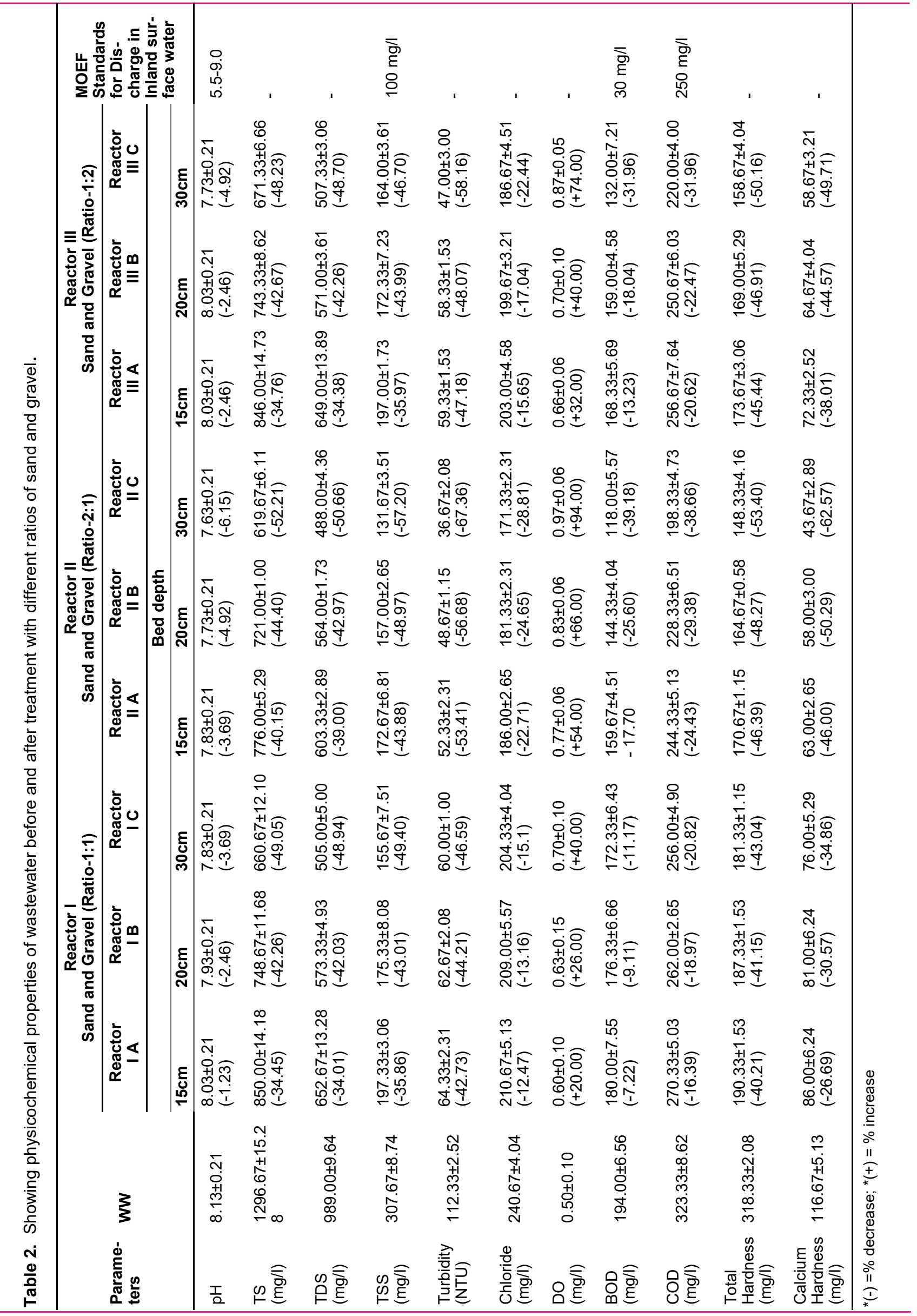


the Reactor II C using $30 \mathrm{~cm}$ depth of filter bed. It was revealed by Shishaye (2017) that the treatment efficiency was inversely proportional to the flow rate (Filter width $66 \mathrm{~cm}$, Horizontal flow filter operated at 0.011 to $0.022 \mathrm{~L} / \mathrm{S}$ ). Prasad et al. (2007) obtained similar results $(68.94 \%)$ for the reduction in turbidity using 1 feet depth of pure sand bed.

The treatment efficiency of the reactors for chloride removal varied from $12.47 \%$ to $28.81 \%$. The maximum reduction was observed $28.81 \%$ (from $240.67 \mathrm{mg} / \mathrm{l}$ to $171.33 \mathrm{mg} / \mathrm{l}$ ) with the Reactor II C using $30 \mathrm{~cm}$ depth of filter bed and the minimum reduction was observed $12.47 \%$ (from $240.67 \mathrm{mg} / \mathrm{l}$ to $210.67 \mathrm{mg} / \mathrm{l}$ ) with the Reactor I A using $10 \mathrm{~cm}$ depth of filter bed. It has been reported that the low values of dissolved oxygen (DO) are associated with heavy contamination by organic matter (Khanna and Bhutiani, 2008). The present study indicated that the increase in $D O$ ranged from $0.60 \mathrm{mg} / \mathrm{l}(20.00 \%)$ in the Reactor I A using 10 $\mathrm{cm}$ depth of filter bed to $0.97 \mathrm{mg} / \mathrm{l}(94.00 \%)$ in the Reactor II C using $30 \mathrm{~cm}$ depth of filter bed. The increase in DO may be due to the reduced amount of organic matter and the simultaneous mixing of atmospheric oxygen during the treatment. Increase in the concentration of DO makes the water suitable for the action (in the absence of oxygen microorganism perform anaerobic degradation which results in other toxic elements and if a small amount of oxygen is present then the degradation will be aerobic which results in final decomposition of waste and enhanced activity of microbes) of aquatic microorganisms.

The reduction in the values of BOD was found in the range of $7.22 \%$ to $39.18 \%$. The maximum reduction in the values of BOD was observed $39.18 \%$ (from 194.0 $\mathrm{mg} / \mathrm{l}$ to $118.00 \mathrm{mg} / \mathrm{l}$ ) with the Reactor II C using $30 \mathrm{~cm}$ depth of filter bed which was above the MOEF standards (2000) for discharge in inland surface water while minimum removal was observed $7.22 \%$ (from $194.0 \mathrm{mg} / \mathrm{l}$ to $180.00 \mathrm{mg} / \mathrm{l}$ ) with the Reactor I A using $10 \mathrm{~cm}$ depth of filter bed. Bellamy et al. (1985) filtered the effluent using the 3.5 feet depth of sand bed containing only sand of $0.3 \mathrm{~mm}$ and then later $0.6 \mathrm{~mm}$ in size and reported more than $65 \%$ reduction in BOD. Prasad et al. (2007) reported that the reduction of BOD was $72.5 \%$ by using 2 feet depth of sand bed containing a mixture of sand and soil in the ratio of $3: 1$ for the treatment of domestic wastewater. It was also reported that the reduction of BOD was due to the reduction of organic matter by microbial population. Khan et al. (2016) obtained $44 \%$ reduction in the BOD of industrial wastewater and $57 \%$ in the BOD of domestic wastewater using a sand bed depth of 20 $\mathrm{cm}$.

The COD removal was observed in the range of $16.39 \%$ to $38.66 \%$. The maximum reduction was $38.66 \%$ (from $323.33 \mathrm{mg} / \mathrm{l}$ to $198.33 \mathrm{mg} / \mathrm{l}$ ) with the
Reactor II C using $30 \mathrm{~cm}$ depth of filter bed which was below the MOEF standards (2000) for discharge in inland surface water while the minimum removal was $16.39 \%$ (from $323.33 \mathrm{mg} / \mathrm{l}$ to $270.33 \mathrm{mg} / \mathrm{l}$ ) with the Reactor I A using $10 \mathrm{~cm}$ depth of filter bed. Ibrahim et al. (2020) obtained $41 \%$ reduction in the COD of agricultural drain water using the only sand bed of depth of $60 \mathrm{~cm}$. Prasad et al. (2007) reported that the reduction of COD was $78.96 \%$ of the domestic wastewater by using 2 feet depth of sand bed containing a mixture of sand and soil in the ratio of 3:1. Al-Enazi et al. (2013) obtained $80 \%$ COD reduction in case of olive mill wastewater using $80 \mathrm{~cm}$ depth of the sand bed.

The reduction in the values of total hardness $(\mathrm{TH})$ ranged from $40.21 \%$ to $53.40 \%$. The maximum reduction was $53.40 \%$ (from $318.33 \mathrm{mg} / \mathrm{l}$ to $148.33 \mathrm{mg} / \mathrm{l}$ ) with the Reactor II C using $30 \mathrm{~cm}$ depth of filter bed while the minimum was $40.21 \%$ (from $318.33 \mathrm{mg} / \mathrm{l}$ to $190.33 \mathrm{mg} / \mathrm{l}$ ) with the Reactor I A using $10 \mathrm{~cm}$ depth of filter bed. The reduction in the values of calcium hardness (CaH) was found in the range of $26.69 \%$ to $62.57 \%$. The maximum reduction was found $62.57 \%$ (from $116.67 \mathrm{mg} / \mathrm{l}$ to $43.67 \mathrm{mg} / \mathrm{l}$ ) with the Reactor II C using $30 \mathrm{~cm}$ depth of filter bed and minimum removal was observed $26.69 \%$ (from $116.67 \mathrm{mg} / \mathrm{l}$ to $86.00 \mathrm{mg} / \mathrm{l}$ ) with the Reactor I A using $10 \mathrm{~cm}$ depth of filter bed.

The strained out algae, microbes and plant debris over the sand layer of SIF promote the decomposition of organic matter by microorganisms. The removal of various parameters was due to mechanical (biosorption, diffusion, screening and sedimentation, biological processes (predation, natural death and metabolic breakdown by the microorganism) and was also due to sticky deposit layer or gelatinous layer over the filter bed which was developed when SIF was provided moisture by raw wastewater for a period of 4 to 6 days. Agarwal et al. (2020) has reported that schmutzdecke grows in very first week of installation of SSF and it contains suspended solids, bacteria, algae, fungi, metal ion etc. Due to removal of organic matter by the microorganisms, endogenous respiration takes place, which also reduces the microbial load over the filter. Efficiency of this filter with regard to removal of organic matter and microorganisms rely on the growth of schmutzdecke.

Given the above results and considering all the physicochemical parameters, the $\mathrm{COD}$ and $\mathrm{pH}$ parameters were below the standard limits (MOEF, 2000) for discharge on inland surface water. However, TSS and BOD were found above the standard limits (MOEF, 2000) to discharge the treated wastewater on the inland surface (Table 2). The technology of Sandintermittent filtration used in the present study does not require any skilled labour and energy. Therefore, it may be a suitable technology after some modifica- 
tion for the underdeveloped and developing nations to treat wastewater for their safe disposal to land.

\section{Conclusion}

Based on the composition and width of filter bed in the Reactors used for the treatment of Industrial wastewater, it was concluded that among all the Reactors, the Reactor II yielded better results in comparison to the Reactor I and III. The maximum removal of TS, TDS, TSS, turbidity, chloride, BOD, COD, TH, and CaH was shown by Reactor II C ( with ratio of soil and gravel 2:1 and $30 \mathrm{~cm}$ depth of bed) due to its maximum width of filter bed as all the other variables were constant (flow rate and particle size). The reduction of physicochemical parameters may be due to both mechanical (biosorption, diffusion, screening and sedimentation) and biological processes (predation, natural death and metabolic breakdown by the microorganism) involved in the treatment of wastewater. The parameters like $\mathrm{pH}$ and COD were within the permissible limit. The Reactors require modification to reduce the parameters like TSS, turbidity further, and BOD to come in the range of standards for their land surface disposal. The SIF technology could be a most affordable, easy to operate and economically viable process.

\section{Conflict of interest}

The authors declare that they have no conflict of interest.

\section{REFERENCES}

1. Agrawal, A., Sharma, N. and Sharma, P. (2020). Designing an economical slow sand filter for households to improve water quality parameters. Materials Today: Proceedings, https://doi.org/10.1016/j.matpr.2020.09.450)

2. Aghalari, Z., Dahms, H. U., Sillanpaa, M., SosaHernandez, J. E. and Parra-Saldívar, R. (2020). Effectiveness of wastewater treatment systems in removing microbial agents: a systematic review. Globalization and Health, 16:3, https://doi.org/10.1186/s12992-020-0546-y.

3. Al-Enazi, M. M., El-Khateeb, M. A. and El-Bahrawy, A. Z. (2013). Combining Chemical Treatment and Sand Filtration for the Olive Mill Wastewater Reclamation. Life Science Journal, 10(3): 583-592.

4. APHA-AWWA-WPCF (2012). Standard Methods for the Examination of Water and Wastewater, $22^{\text {nd }}$ edition. Water Environment Federation Washington, DC.

5. Aslam, M. M., Malik, M., Baig, M. A., Qazi, I. A. and Iqbal, J. (2007). Treatment performances of compost-based and gravel-based vertical flow wetlands operated identically for refinery wastewater treatment in Pakistan. Ecological engineering, 30: 34-42.

6. Bellamy, W. D., Hendricks, D. W. and Logsdon, G. S. (1985). Slow Sand Filtration Influences of Selected Process Variables. Journal of American Water Works Association, 77(12): 62-66.
7. Bhausaheb, L., Pangarkar, B., Parjane, S. and Sane, M. G. (2010). Design and Economical Performance of Gray Water Treatment Plant in Rural Region. World Academy of Science, Engineering and Technology, 37: 896-900.

8. Bhutiani, R., Pratap, H., Ahamad, F., Kumar, P. and Kaushik, P. D. (2017). Efficiency Assessment of Effluent Treatment Plant (ETP) Treating an Automobile Industry Effluent (Sidcul) Haridwar. Environment Conservation Journal, 18(1\&2): 95-102.

9. Campos, L., Su, M. F. J., Graham, N. J. D. and Smith, S. R. (2002). Biomass development in slow sand filters. Water Research, 36: 4543-4551.

10. Cheremisinoff, P. N. (2019). Hand book of water and wastewater treatment technology, CRC press, Boca Raton, UK.

11. Chuang, Y. H., Wang, G. S. and Tung, H. (2011). Chlorine residuals and haloacetic acid reduction in rapid sand filtration. Chemosphere, 85(7): 1146-53.

12. D'Alessio, M., Yoneyama, B., Kirs, M., Kisand, V. and Ray, C. (2015). Pharmaceutically active compounds: Their removal during slow sand filtration and their impact on slow sand filtration bacterial removal. Science of the Total Environment,; 24-135.

13. Ibrahim, K. A. I., Ahmed, S. I. A., El-Gendy, A. S. and Sabry, T. I. M. (2020). Effect of Media Properties on Performance of Sand Filtration for Drain Water Treatment. www.preprints.org, doi:10.20944/preprints202003.0112.v1

14. IWMI (2007). India's water future to 2025-2050: Businessas-usual scenario and deviations. Colombo, Sri Lanka: International Water Management Institute (IWMI). (IWMI Research Report 123).

15. Khan, T. A., Rehman, K. and Sheraz, K. (2016). Development and Testing of Low Cost Sand Filter for the Treatment of Industrial and Domestic Wastewater. International Journal of Engineering Research \& Technology (IJERT), 5 (2): 504-511.

16. Khanna, D. R. and Bhutiani, R. (2008). Laboratory manual of water and Waste water Analysis. Daya Publishing House New Delhi -110002.

17. Matuzahroh, N., Fitriani, N., Ardiyanti, P. E., Kuncoro, E. P., Budiyanto, W. D., Isnadina, D. R. M., Wahyudianto, F. E. and Mohamed, R. M. S. R. (2020). Behaviour of schmutzdecke with varied filtration rates of slow sand filter to remove total coliforms. Heliyon 6: e03736.

18. MOEF (2000). Environmental Standards. Part C (General Standards for Discharge of Environmental Pollutants). Issued by Ministry of Environment and Forests (MoEF) Vide Notification No. GSR-742 E dt. 25.09.2000.

19. Ochoa, S. I. C., Ushijima, K., Hijikata, N. and Funamizu, N. (2018). Treatment of Greywater by Geotextile Filter and Intermittent Sand Filtration. N. Funamizu (ed.), ResourceOriented Agro-sanitation Systems, https:// doi.org/10.1007/978-4-431-56835-3_14, pp-195-210.

20. Prasad, G., Rajput, R. and Chopra, A. K. (2006). Sand Intermittent Filtration Technology for safer Domestic Sewage Treatment. Journal of Applied Sciences and Environmental Management, 10(1): 73 -77.

21. Prasad, G., Rajput, R. and Chopra, A. K. (2007). Alternative economic technology for treatment of distillery effluent to prevent surface and ground water pollution. Journal of Applied Sciences and Environmental Management, 11(3): 35-39. 
22. Ranjan, P. and Prem, M. (2018). Schmutzdecke- A Filtration Layer of Slow Sand Filter. International Journal of Current Microbiology and Applied Sciences, 7(7): 637-645.

23. Ruhela, M. Bhutiani, R. Ahamad, F. and Khanna, D. R (2019). Impact of Hindon River Water on Selected Riparian Flora (Azadirachta Indica and Acacia Nilotica) with special Reference to Heavy Metals. Pollution, 5(4): 749760.

24. Sahu, S. N., Sahoo, N. K. and Naik, S. N. (2019). Phy- coremediation Technology: A Global prospective. In: Application of Microalgae in Wastewater Treatment Volume 1: Domestic and Industrial Wastewater Treatment, Edited by Gupta, S. K. and Bux, F. pp-1-18.

25. Shishaye, H. A. (2017). Design and Evaluation of Household Horizontal Slow Sand Filter. Current Journal of Applied Science and Technology, 23(1): 1-10.

26. Zheng, X., Mehrez, R., Jekel, M. and Ernst, M. (2009). Effect of slow sand filtration of treated wastewater as pretreatment to UF. Desalination, 249: 591-595. 